\title{
philosophising with young children as a language-promoting principle
}

\author{
katrin alt ${ }^{1}$ \\ university of bremen and hamburg, germany \\ orcid id: https:/ / orcid.org/0000-0003-4067-8740
}

\begin{abstract}
Children develop language and communication skills through interaction with adults and other children. This study therefore focuses on two interdependent issues: the effect of philosophizing with children on children's language development and the speech acts of teachers and children in philosophical enquiries. As part of a before-after test with the "Hamburger Verfahren zur Analyse des Sprachstandes Fünfjähriger" (Reich \& Roth, 2004, Hamburg Procedure for Analysing the Language Level of Five Year-olds), weekly philosophical discussions were undertaken with a test class over a period of six months. The central findings are that the philosophising children developed significantly higher language ability compared with a non-philosophising control class in two areas, namely general performance in discussion and the use of more sophisticated connectors. A further part of the study compared the speech acts of the children and their pre-school teacher in the context of philosophical discussion with their speech acts in a different dialogic situation (dialogic discussion of picture books). This showed that philosophical questions from the pre-school teacher led to the production of particularly complex language by the children. Complex speech acts involve the use of higher-level verb structures and connectors. These are necessary in order to reason and act as a citizen agent and are supported by philosophising with children, as this study shows.
\end{abstract}

keywords: philosophical enquiry enhanced through picture books; language promotion; preschool children

\section{filosofar com crianças pequenas como princípio de promoção de línguas ou linguagem}

\section{resumo}

Crianças desenvolvem habilidades de comunicação e linguagem através de sua interação com adultos e outras crianças. Este estudo, assim sendo, se debruça sobre duas questões independentes: os efeitos da filosofia com crianças em seu desenvolvimento linguístico e os atos discursivos de professorxs e crianças em investigações filosóficas. Como parte de um teste comparativo do tipo "antes-depois" com o "Hamburger Verfahren zur Analyse des Sprachstandes Fünfjähriger" (Reich \& Roth, 2004, Procedimento de Hamburgo para Análise de Nível Linguístico de Crianças de Cinco Anos), discussões filosóficas semanais foram realizadas com uma turma de teste por um período de seis meses. As descobertas centrais foram de que as crianças que filosofavam desenvolveram habilidades linguísticas significativamente mais avançadas comparadas a um grupo de controle que não trabalhou com a filosofia, em duas áreas, a saber: desempenho geral em discussões e o uso de conectores mais sofisticados. Uma parte subsequente do estudo comparou os atos discursivos das crianças e seus/suas professorxs no contexto das discussões filosóficas com seus atos discursivos numa situação dialógica diferente (diálogo sobre livros de ilustrações). Isto mostrou que as questões filosóficas que partiram $\mathrm{dx}$ professorx da pré-escola levaram à produção de uma linguagem particularmente complexa pelas crianças. Atos discursivos complexos

\footnotetext{
${ }^{1}$ Email: katrin.alt@uni-hamburg.de 
philosophising with young children as a language-promoting principle

envolvem o uso de estruturas verbais e conectores de alto nível linguístico. Estes são necessários para racionalizar e atuar na realidade como cidadão, e este estudo mostra como seu desenvolvimento está aliado à filosofia com crianças.

palavras-chave: investigação filosófica potencializada através de livros de ilustrações; desenvolvimento linguístico; crianças na educação infantil

\section{filosofar con niños pequeños como principio promotor del linguaje}

\section{resumen}

Los niños desarrollan habilidades de lenguaje y comunicación a través de la interacción con adultos y otros niños. Por consiguiente, este estudio se centra en dos cuestiones independientes: el efecto del filosofar con niños en su desarrollo lingüístico y los actos de habla de maestros y niños en las investigaciones filosóficas. Como parte de una prueba comparativa de "antes-después" con el "Hamburger Verfahren zur Analyse des Sprachstandes Fünfjähriger" (Reich \& Roth, 2004, Método de Hamburgo para el Análisis del Nivel Lingüístico de Niños de Cinco Años), se realizaron discusiones filosóficas semanales con un grupo de testeo por un período de seis meses. Los hallazgos centrales son que los niños que hacían filosofía desarrollaron habilidades lingüísticas significativamente superiores en comparación con una clase de control que no hacía filosofía, en dos áreas, a saber: el rendimiento general en la discusión y el uso de conectores más sofisticados. Más adelante, otra parte del estudio comparó los actos de habla de los niños y sus maestros de preescolar en el contexto de las discusiones filosóficas con sus actos de habla en una situación dialógica diferente (discusión dialogada sobre libros de ilustración). Esto mostró que las preguntas filosóficas de los maestros de preescolar condujeron a los niños a la producción de un lenguaje particularmente complejo. Los actos de habla complejos implican el uso de estructuras verbales y conectores de alto nivel lingüístico. Éstos son necesarios para razonar y actuar como agentes ciudadanos, y se ven favorecidos por el filosofar con niños, como este estudio muestra.

palabras clave: investigación filosófica potenciada a través de libros de ilustración; desarrollo lingüístico; niños en prescolar 
philosophising with young children as a language-promoting principle

\section{language development at pre-school age}

Linguistic ability is not only of great importance for success at school but also for participation in society. Although everyday linguistic competence enables us to cope in many situations, more specialised discussion or debate requires us to access more complex linguistic material if we wish to contribute reasoned argument to the discourse. The ability to express one's own opinion, to position oneself and to argue in favour of it are important developmental tasks, even at pre-school age, that are in turn linked to fundamental linguistic skills. Children gradually have to learn how to use subordinate clauses initiated by connectors, deploy more advanced verb forms (such as the subjunctive) and develop and differentiate concepts. Children who are transitioning from pre-school to primary school face the challenge of expanding their everyday linguistic register to include academic language. Complex speech acts such as making an argument or formulating an assumption are associated with the use of academic language (Feilke, 2013; Hövelbrinks, 2014) and should be supported by education.

\section{speech acts of 5-6-year-olds}

In this study, we examine the issue of whether philosophising with children can promote and stimulate particularly complex speech acts. At its centre lies the assumption that the cognitively stimulating content of open questions to which there is no generally accepted answer, questions that are open not only in a grammatical but above all in a conceptual sense (Worley, 2015), require particularly complex language.

Following the RaBi Scale (Tietze, Rank, \& Wildemann, 2016, p.34), this study took the complex speech acts of explanation, justification and supposition as categories for analysis. Since explanation and justification are hard to distinguish from one another, the category of argumentation was used to refer to both. Two further speech acts were added that are characteristic of philosophical conversations: explanation of terms and expression of opinions in the form of positioning oneself. 
philosophising with young children as a language-promoting principle

Neither the potential of philosophising with children to generate complex speech acts nor the effect of philosophising on children's speech acts has thus far been examined at a micro level. It is assumed that philosophical discussion can actively support children's learning in this area because its targeted discussion stimuli, based on approaches to philosophy teaching (Michalik, 2006, 2010)2, explicitly challenge children to explain terms, express and justify their opinions and engage in speculation.

In order to be able to describe speech acts more precisely at the micro-level, further fine-grain categories (in line with HAVAS 5) were created to analyse the children's language at a morphological and syntactic level. The key evaluation criteria for the philosophical discussions were the use of verbs in relation to structure and position, and the use of connectors.

\section{speech acts of pre-school teachers}

Education professionals can prompt linguistic expression by the use of targeted stimuli and questions. Current German-language research regards the promotion of "long-lasting utterances" (König, 2006) and “overset-style explanations" (Heller \& Morek, 2015) as particularly worthy of support. The combination of initial closed (yes/no questions) expanding into a second stage with open questions geared towards explanation (Morek, 2011, p. 223) is particularly challenging for children in terms of language and cognition. Philosophical discussion always takes a two-stage approach, where children are asked to position themselves in relation to a question or a situation and then to justify their position or opinion. Not all open questions, when these are considered more closely, are equally conducive to the production of arguments (see the results of this study). For this study, therefore, we divided open questions into two different types (grammatically open vs. conceptually open) in keeping with Worley (2015). Conventional language teaching strategies for language acquisition and development, such as expansions, extensions and

\footnotetext{
${ }^{2}$ The stimuli developed by Kerstin Michalik include for example stimuli that "require [children to produce] examples and counter-examples", that prompt children "to act out consequences and effects" or "to put statements forward for discussion once again and provoke the consideration of alternatives" (Michalik 2006, 2010). The stimuli are all illustrated by examples questions.
} 
corrective feedback, can also be deployed in philosophical discussion in order to provide children with support in relation to issues such as vocabulary, morphology and syntax. The overarching question in this study for the analysis of transcripts relating to speech acts of pre-school teachers is whether discussion content (philosophical/non-philosophical) influences discussion structure to the extent that the associated potential for language promotion is different where language teaching strategies and different question types are used.

\section{philosophising with children and language acquisition - research status}

It has already been shown that children who philosophise regularly are able to increase levels of exchange with their peers as compared with exchanges with the teacher (Daniel, Lafortune, Pallascio, \& Schleifer, 1999; Thompson \& Dupuis, 1979; Trickey, 2007). There are also preliminary indications of the development of argumentation skills (Niklasson, Ohlsson, \& Ringborg, 1996; Trickey, 2007) and an expanded and increased use of connectors in the context of philosophical conversations (Schleifer \& Courtemanche, 1996; Gholamhossein \& Siamak, 2010) The qualitatively focused studies by the research group associated with Marie-France Daniel state that the dialogic ability of children who regularly philosophise develops from exchanges that tend to be anecdotal and monologic into those that are more dialogic and critical (Daniel, et al., 1999; Daniel \& Delsol, 2005; Daniel, Pettier \& AuriacSlusarczyk, 2011).

As far as the linguistic activity of teachers is concerned, it has become clear that a higher proportion of open-ended questions are used in the context of philosophical discussions (Trickey, 2007) and that philosophical questions from teachers were particularly effective at stimulating communication (Gholamhossein \& Siamak, 2010).

\section{philosophising with children using picture books}

The intervention for the test class consisted of weekly philosophical discussions initiated by means of picture books and taking the form of a "Community of Enquiry". The sessions were always structured in a similar way: to begin with the 
philosophising with young children as a language-promoting principle

story was read aloud, then there was a discussion with prepared philosophical stimulus questions, followed by a concluding meta-conversation about the philosophical discussion.

Picture books are especially suited to philosophising with children, because they work via pictures, text, and the interrelationship between picture and text. Sometimes the texts and pictures contradict each other, thus offering useful opportunities for reflection. Such contradictions can be used as springboards for philosophising. The pictures themselves, along with the content of stories, can be used to stimulate discussion of the attitudes and actions of the protagonists. German literary education expert Kaspar Spinner has identified eleven aspects of literary learning (Spinner, 2006); these overlap to some extent with descriptions of the philosophy with children methodology. For example, Spinner speaks about the importance of developing an ability to handle the "inconclusiveness in the construction of meaning" in relation to ambiguous texts. Children should be given the opportunity to learn how to cope with the "openness" of literary texts. Literature, according to Spinner, enables discussion of complex contexts and ambivalence (Spinner, 2006, p.12).

Ekkehard Martens describes the exploration of interpretative patterns as a key way of approaching philosophical questions in the context of philosophy teaching. This hermeneutic approach, which is characterised by the attempt to understand both one's own and others' interpretations, it is situated at exactly this point (Martens, 2002, p.17). The ambivalent text and its pictures enable two things to occur: on the one hand the development of one's own interpretations and interpretative patterns, and on the other hand, learning about how to cope with ambiguity.

Picture books are therefore suitable for philosophising with children if they offer us voids, i.e. if they leave space for interpretation or ambivalence: "Voids challenge us. They set us moving, forcing us to adopt a position. Voids are key moments for the initiation of productive discussion (hypothetical thinking)" (Hering, 2010, p.12, translated by Alt). Suitable picture books trigger questions, provoke contradictions and support imaginative approaches. Contradictions set one's own 
thoughts running, imaginative approaches can take the form of thought experiments, for example, and thereby support thinking about what is possible. These are approaches that are used in literature, art and also philosophy teaching in order to spark (philosophical) conversations with children. Heike de Boer and Catharina Fuhrmann distinguish between philosophical and literary discussion as follows:

philosophising with a picture book is distinguished from discussion of a book that is being read aloud [...] by the fact that in the context philosophical discussion, the picture book serves merely to provide topics and stimulate discussion. A discussion of a book that is being read aloud focusses on literary learning and an in-depth exploration of the picture book, with the discussion concentrating on the literary text (de Boer \& Fuhrmann, 2015, p. 168, translated by Alt).

A literary discussion can thus be philosophical in nature, but a philosophical discussion is not necessarily literary in nature. Whereas in the literary discussion, the focus is on the book or the story and one's own experiences can play an important role in the topic under discussion, at the core of philosophical discussions the philosophising about open questions. There is currently little literature about philosophising with children using picture books; philosophical discussion has not yet been systematically differentiated from other discussions such as literary ones. One exception is the conceptual study by Joanna Haynes and Karen Murris (Haynes \& Murris, 2012), which summarises criteria for the selection of picture books for philosophising with children, differentiating between epistemological, ethical and political as well as aesthetic requirements (Haynes \& Murris, 2012, pp. 119-121). These criteria were taken into consideration when selecting the picture books for the present study.

\section{study assumptions}

Philosophising with children as a teaching principle or educational principle can be used to promote cognitively stimulating conversations and to explore content in a deeper way. In the sense of "sustained shared thinking (Siraj-Blatchford, 2009) or "dialogically developing thought processes" (König, 2012, p. 32, translated by Alt), philosophical discussions can bring about lengthy interactions and there- 
philosophising with young children as a language-promoting principle

fore be cognitively and linguistically stimulating. They therefore meet current requirements for changing communication in the elementary and primary sectors (cf. Röhner, König, Hövelbrinks, \& Archie, 2015).

The assumption for the empirical study is that the philosophical content of the children's conversations stimulates particularly complex linguistic activity in them, which is demonstrated in their speech acts and evidenced both in morphology and syntax. They formulate their opinion, take a position and justify that position by argumentation. Speculation and imaginative thinking in the form of thought experiments is a central approach for philosophising. If children speak of "possibilities" during philosophical discussion, they are making assumptions. This complex speech act is shown in German by the use of the subjunctive.

The comparison of the two forms of discussion (philosophical/dialogical) in this study illustrates how these differences are represented in the linguistic activity of the children and the pre-school teacher. It is assumed that the philosophical questions, being open questions in terms of content, are particularly effective at provoking speech acts.

\section{study concept}

The intervention consisted of 23 philosophical discussions, undertaken over a period of six months and initiated using picture books. Three philosophical discussions and two dialogic readings of picture books (for the purposes of comparison) were transcribed, evaluated and analysed in terms of their content according to pre-defined deductive categories and with the help of the MAXQDA@ programme. To ensure the philosophical discussions were of an appropriate quality, the pre-school teacher was given 10 hours of training on the principles of philosophising with children and also the educational concept of dialogic picture book reading. Dialogic picture book reading was selected as a comparator as it is one of the most thoroughly studied dialogic discussions at preschool level. Its beneficial effect on children's language development has already been verified by several studies (Ennemoser, Kuhl, \& Pepouna, 2013; Mol, Bus, de Jong, \& Smeets, 2008; Whitehurst, et al., 1988). Dialogue is at the heart of both types of discussion. However, the dialogues have the following differences when it comes to content: the core 
of philosophical discussion is unexplained, final, open or even philosophical questions. There are overlaps in the educational concepts of dialogic reading (as a form of literary discussion) and philosophising with children that have not yet been systematically collated. It depends on the picture book chosen and the discussion participants themselves as to whether philosophical questions determine the topic under discussion.

\section{study questions}

Since language and communication skills develop through interaction, this study focuses on two interdependent elements: the effects of philosophising with children on child language development and the speech acts of the pre-school teacher in philosophical discussions with the children. The following questions are investigated:

1. How does children's use of complex connectors and complex verb forms develop, in the context of a before-after test (language test: HAVAS 5) carried out in a control group study?

2. What are the speech acts of the children and the pre-school teacher in two different dialogic situations (philosophical/non-philosophical)?

The following questions are explored using language test evaluations:

Do children ( $\mathrm{n}=39$ children) who philosophise for six months develop:

- more sophisticated verb positioning (measured in stages),

- more sophisticated connections (connectors, measured in stages),

- more sophisticated communication skills (pragmatic development), ascertained on the basis of observation criteria, than the children in the control group without this specific support? The control group was given weekly dialogic picture book sessions. Groups' language data was evaluated using SPSSC.

This was followed by systematic comparison with dialogic picture book sessions to analyse the specific potential of philosophical discussion for language acquisition. These discussions were held in the test group, i.e. with the same preschool teacher and the same children. Here the following questions were explored: 
philosophising with young children as a language-promoting principle

- Do children deploy high-quality speech acts more frequently, e.g. explanation of terms, positioning, argumentation and suppositions, in in philosophical discussions?

- How is the children's speech structured in relation to morphology and syntax? Which verb forms and sentence connectors do the children use?

As far as the speech acts of the pre-school teacher were concerned, the following points were examined:

- Does she use specific techniques to promote philosophical discussion (in line with Michalik, 2006, 2010)?

- Does she give the children feedback on their language use in the form of corrections, expansions and extensions?

- What is the relationship between the yes-no questions, probing questions and open questions deployed (open questions are differentiated between grammatically open and conceptually open questions according to Worley, 2015)?

\section{havas 5 evaluation}

In relation to the study focus of "sentence connection" and "discussion performance", the study led to significant benefits for the test group and confirmed our hypotheses as follows. After six months of weekly philosophising, children from the test group were more advanced in their use of sentence connectors than children from the control group. They were approximately half a stage ( 0.43 precisely) ahead of the results of the control group out of a total of five stages. The following hypothesis were be confirmed in relation to the children's performance in discussion: Children who philosophised regularly for six months improved their discussion performance in relation to initiative and continuity in conversation, fluency and clarity of speaking compared with the control group by 1.47 points (from a maximum of 12 achievable points). ${ }^{3}$

\footnotetext{
${ }^{3}$ The calculation of significance was undertaken using the IBM statistic programme SPSS $\odot$, version 21. As the data was at least ordinally scaled, the Wilcoxon-Mann-Whitney- Test (U-Test) (a nonparametric test for two independent samples) was available to calculate significance and normal 
The hypothesis that children who philosophised regularly for six months would show stronger development in relation to verb forms and verb placement in comparison with the control group could not be confirmed here. This question will be explored further in the evaluation of comparative discussion data. The absence of a significant increase in Havas testing does not imply that sophisticated verb forms are not (particularly) used in philosophical discussion. We suspect that the instrument itself does not model sophisticated verb forms such as the subjunctive sufficiently. A more suitable test instrument does not yet exist for German-speaking countries.

\section{evaluation of transcripts}

The overarching question for the analysis of discussion transcripts was whether children evinced particularly complex linguistic activity in philosophical discussions compared with discussions in other lessons or groups, and whether the speech acts of the teacher show specific characteristics. The overall number of utterances by the children for three philosophical discussions was 506 compared with 246 utterances for two dialogic picture book sessions. Speaker ratios were more or less equally divided in both discussions, with $54 \%$ of the children contributing during philosophical discussion compared with $52 \%$ in dialogic picture book sessions. There was therefore no significant difference between the groups in relation to who spoke. It was noticeable that the children in the philosophical discussion...

- used explanatory terms twice as often,

- took up a position almost twice as often,

- justified their opinions more often (12\% in philosophical discussions compared with $5 \%$ in dialogic reading sessions)

- and voiced suppositions, even if only in $2 \%$ of utterances, in philosophical discussion compared with $0 \%$ in dialogic picture book sessions.

distribution. At measurement point 1, the two groups did not differ significantly from each other. At measurement point 2 , the asymptotic significance for both discussion performance and sentence connection was 0.033 and 0.041 ; rounded off this data differs with a probability of $97 \%$ and $96 \%$. 
philosophising with young children as a language-promoting principle

In total, $37 \%$ of the children's utterances in philosophical discussion could be categorised as explanation of terms, adopting a position, argumentation or supposition; whereas in the dialogical picture book reading this figure was only $16 \%$ (Table 1). The speech acts of the children differed depending on the situation, so that the hypothesis "The children in the philosophical discussions explain terms to a greater degree, adopt a position more often, use more argumentation and voice suppositions more often," can be confirmed.

Table 1: Speech acts of the children in the different situations: broad categories ${ }^{4}$

\begin{tabular}{lcc} 
Categories & $\begin{array}{c}\text { Philosophical } \\
\text { discussions (in \%) } \\
N=506 \text { utterances }\end{array}$ & $\begin{array}{c}\text { Dialogic picture book } \\
\text { session (in \%) } \\
N=164 \text { utterances }\end{array}$ \\
\hline Explanation of terms & 7 & 4 \\
Positioning & 16 & 7 \\
Argumentation & 12 & 5 \\
Supposition & 2 & 0 \\
Overall proportion & 37 & 16 \\
\hline
\end{tabular}

Detailed analysis demonstrates that differences in speech acts are also visible at the linguistic level, in relation to particularly sophisticated verb forms and sentence connectors (based on HAVAS 5 stages). For example, 2\% of the verbs used by the children in philosophical discussion were formulated in the subjunctive. In the dialogic reading sessions, the subjunctive did not arise. This shows that philosophical discussion particularly challenges participants to think in terms of possibilities and alternatives and to weigh up hypothetical outcomes, for example in the context of the thought experiment method that explicitly focuses on speculative thought (cf. Martens 2002, p. 17). Speculative thought (“What if...") requires the use of the subjunctive and then implicitly promotes the use of this verb form.

The verb forms used in philosophical discussion are more sophisticated than those in dialogic picture book reading. It can therefore be deduced that philosophical discussion particularly stimulates the use of complex verb forms. Quantitative analysis (results HAVAS 5) could not confirm this here. It would be necessary to check whether a more suitable test procedure on the use of the subjunctive would

\footnotetext{
${ }^{4}$ Formula for calculation: Percentage $=\frac{\text { absolute value } \times 100}{\text { Number of utterances children in conversation }}$
} 
have given other results. The following table compares the verb forms used in the two situations. Adding up the percentages from stage four shows that in the philosophical discussions, $11 \%$ of verb forms are categorised as stage four or five; for the dialogic reading sessions, however, this figure is only $2 \%$. The highest verb form produced in the dialogical picture book sessions was the perfect tense, whereas the children in the philosophical discussions also used the passive, the statal passive, the future and the subjunctive.

The total number of connectors used (200 in the philosophical discussions compared with 25 in the dialogic picture book readings) already makes it clear that there the two forms of discussion show structural differences in the form of absolute connectors used. The quality of connectors used also differs; when considered in relation to the stages, the ones from philosophical discussions are markedly more sophisticated than those from dialogic picture book readings. It can therefore be deduced that philosophical discussions particularly stimulate the use of connectors in general and complex connectors in particular. The frequency of subordinate clause structures using the connectors "aber" ("but"), "dass" ("that") and "damit" ("so that") is especially high in the philosophical discussions. For the connectors "denn" ("for"), "ob" ("whether") and "als" ("as") there are no or only minimal differences. Out of a maximum of $74 \%$, the children in the philosophical discussions produced sentence connectors from stage 4; whereas in the dialogic reading sessions only $32 \%$ of sentence connectors are at or beyond this stage. In summary, it can be confirmed that the children's speech acts in the philosophical discussions used particularly complex sentence connectors and that it was characterised by sophisticated morphological and syntactic linguistic structures.

Evaluation of the pre-school teacher's speech acts in the two discussions also reveals differences. Her speech acts were examined at two different levels; on the one hand, the language teaching strategies used and on the other, her questioning techniques. In the philosophical discussions ...

- she gave double the amount of corrective feedback,

- there were only minimal differences in relation to expansions and extensions, 
philosophising with young children as a language-promoting principle

- overall the number of language teaching strategies (corrective feedback, expansion, extension) deployed was almost twice as high (this can be ascribed above all to the use of corrective feedback).

In relation to the questions posed by the teacher, it can be confirmed that she posed a higher proportion of open questions in the philosophical discussions than in the dialogic picture book sessions. It was also confirmed that the proportion of yes-no questions was higher and the number of probing questions lower in philosophical discussion.

Table 2: Comparison of pre-school teacher speech acts: questions

\begin{tabular}{lcc} 
Questions used & $\begin{array}{c}\text { Philosophical dis- } \\
\text { cussions in } \% \\
N=240\end{array}$ & $\begin{array}{c}\text { Dialogic picture } \\
\text { book session in \% } \\
N=118\end{array}$ \\
\hline Yes-no questions & 52 & 44 \\
Probing questions & 8 & 22 \\
Open questions & 40 & 34 \\
$\quad$ Grammatically open questions & 59 & 100 \\
Conceptually open questions $^{6}$ & 51 & 0 \\
\hline
\end{tabular}

In both discussion situations, yes-no questions were ranked first, open questions second and probing questions third. The value for probing questions was the most divergent. For example in the philosophical discussions, only $8 \%$ of the questions were probing questions, whereas the proportion for the dialogic picture book sessions was $22 \%$. Therefore the proportion of probing questions in dialogic picture book sessions was approximately three times as high as in philosophical discussions. In the philosophical discussions, the proportion of open questions (40\%) was higher than in the dialogic picture book sessions (34\%). Even more interesting is the evaluation of the two different open question types, because whereas in the philosophical discussions, the proportion of grammatically open questions (48\%) and the conceptually open questions (51\%) was relatively equally distributed, there were

\footnotetext{
${ }^{5}$ The percentage value of grammatically and conceptionally open questions is based on the overall number of open questions and not, as with the other questions, on the overall number of questions asked.

${ }^{6}$ Equally, see footnote 3.
} 
only grammatically open questions $(100 \%)$ present in the dialogic picture book sessions. No conceptually open questions were raised here.

\section{summary of findings}

This study delivered two central findings: On the one hand, comparison of the groups using HAVAS 5 testing proved that the children in the philosophising group showed better development than the control group in two areas: communication skills and the use of sentence connectors. Secondly, comparison and evaluation of discussion transcripts showed that speech acts in philosophical discussion clearly differ from those in other dialogic situations (here, dialogic picture book sessions). Comparative evaluation also offers an explanation for the children's language test results. The children in the test group used around twice as many explanatory terms and sophisticated argumentation (identified by use of connectors), and adopted a position twice as often, in philosophical discussions. Suppositions in the subjunctive were voiced, even if only in minimal numbers; this can also be explained by the age of the children. To summarise, the comparative analysis supports the conclusion that philosophical discussions clearly demand more sophisticated verb usage of children, sometimes even in the form of the subjunctive, and lead to the use of higher quality sentence connections. The conclusion can be drawn that philosophical discussions contribute to the use of particularly complex morphology and syntax and therefore to the use of complex language use.

In relation to the speech acts of the pre-school teacher, it can be summarised that she adapted her speech acts to each situation. For example, she behaved in a more linguistically challenging way in the philosophical discussions than in the dialogic picture book sessions. From this it can be concluded that the different stimuli developed for philosophical discussion (Michalik, 2006, 2010) are particularly effective at stimulating language and therefore also promote cognitively stimulating conversations.

The promotion of formal aspects of language by the pre-school teacher also differs in the two discussion situations. The pre-school teacher gave corrective feedback more frequently in philosophical discussions. This result is surprising because corrective feedback is a language teaching strategy that is recommended specially 
philosophising with young children as a language-promoting principle

for the promotion of language in dialogic picture book sessions (cf. Zevenbergen \& Whitehurst, 2003). Overall (in relation to corrective feedback, expansions and extensions) the pre-school teacher used almost twice as many language teaching strategies $(11 \%)$ in the philosophical discussions than she did in the dialogic picture book sessions $(6 \%)$. One possible explanation is that in the philosophical discussion she paid more attention to the accuracy of the children's language. The conceptual process (e.g. explaining terms) is one of the most important elements of philosophising with children (Martens, 1999; Brüning, 2010). It is thus associated with particular attention to the clarity of language. This explanatory approach is supported by the high number of stimuli from the pre-school teacher in the philosophical discussions focussing on the explanation of terms7 (9\%); in comparison, the figure for in the dialogic picture book session was only $3 \%$. In a questionnaire completed by the preschool teacher in advance, she named the explanation of terms to be one of the central language-promoting functions of work with picture books in her group. She then deployed this in the philosophical discussions more strongly than in the dialogic picture book sessions.

In relation to questions, the proportion of probing questions (simple w-questions such as: Who is that? What is that?) in the dialogic picture book sessions was almost three times as high as in the philosophical discussions. The speech acts of the pre-school teacher in relation to this type of question correspond to the theoretical requirements for running dialogic picture book sessions. Whitehurst et al. (1988, p.552 et seqq.) describe the use of probe questions alongside the use of open questions as one of the most important techniques for dialogic reading of picture books.

In the philosophical discussions, the proportion of yes-no questions and open questions was higher than for the dialogic picture book sessions. This difference was to be expected because the request to adopt and justify a position is mostly made in the form of these two question types and is characteristic of the speech acts of discussion leaders in philosophical discussion. Detailed analysis of the open

\footnotetext{
${ }^{7}$ Probe questions for the purpose of the pure naming of objects, animals, persons on the pictures in the context of "what is that?", "who is that?" were not counted as impulses for explaining terms.
} 
questions, however, also shows that in the dialogic picture book sessions only grammatically open questions were posed that were often geared towards the understanding of the story itself; whereas in the philosophical discussions, over $50 \%$ including conceptually open questions, i.e. philosophical questions, were posed to which there are no generally accepted answers.

A further conclusion in relation to the speech acts of the pre-school teacher is that the educational task of exploring a picture book philosophically with the children leads to a conversation that is cognitively and linguistically more richly stimulating than working according to the principles of dialogic picture book reading. The results relating to the speech acts of the pre-school teacher lead to two conclusions for the development of concepts in educational practice. For very young children and children who do not have German as a first language, who are just starting to learn German and still need to expand their vocabulary significantly, the dialogic picture book session is a simpler setting in which to start learning the German language. Many simple probing questions are posed here and children can join in and communicate even if they only have a few words. For older pre-school children and primary school children who already have a grasp of basic vocabulary and grammatical structures, philosophical discussion offers particular potential. Here children learn to express a position and justify it, to explain terms and formulate suppositions. They use particularly demanding morphological and syntactic structures and their academic language skills are challenged more strongly.

\section{future prospects}

Additional research questions for a follow-up study might be:

- Is it possible to confirm the influence of philosophical content on the grammatical complexity of children's utterances in a larger test sample?

- Can primary school-age children be encouraged (even more strongly) to use the subjunctive in philosophical discussion? ${ }^{8}$

\footnotetext{
${ }^{8}$ In this study, it is true that in small sample sizes it could be observed that children use the subjunctive in philosophical discussion, but further confirmation for older children would be interesting because many children first acquire the subjunctive at primary school age.
} 
philosophising with young children as a language-promoting principle

- Are the results of this study regarding the variance in the teacher's questioning technique in different situations replicated for a wider sample of teachers with differing teaching styles?

Language is the medium that allows us to integrate into society and actively help to shape it. Philosophising with children offers special potential for promoting language development. Open questions that challenge children in relation to content help them to acquire terms, learn to disagree about opinions and positions and argue in favour of them. Complex linguistic abilities are particularly activated here; these are particularly important for making an argument. Philosophising with children is therefore a principle of learning and education that not only supplements the content of lessons and group discussions, but also supports the development of complex speech acts. More widespread integration of philosophising with children into training for teachers and social education professionals, as part of languagepromotion work in daycare centres, pre-schools and schools, is desirable.

\section{references}

BRÜNING, B. (2010). Philosophieren in der Grundschule: Grundlagen, Methoden und Anregungen. Berlin: Cornelsen Scriptor.

DANIEL, M.-F., LAFORTUNE, L., PALLASCIO, R., \& SCHLEIFER, M. (1999). Philosophical Reflection and Cooperative Practices in an Elementary School Mathematics Classroom. Canadian Journal of Education 24 (4), 426-440.

DANIEL, M.-F., PETTIER, J. C., \& AURIAC-SLUSARCZYK, E. (2011). The Incidence of Philosophy on Discursive and Language Competence in Four-Year-Old-Pupils. Creative Education, 2 (3), 296-304.

DANIEL, M.-F., \& DELSOL, A. (2005). Learning to dialogue in Kindergarten. A Case Study. Analytic teaching, 25 (3), 23-52.

BOER, H. de, \& FUHRMANN, C. (2015). Mit Bilderbüchern philosophieren. In M. Dehn \& D. Merklinger (Eds.), Erzählen - Vorlesen - zum Schmökern anregen. Frankfurt a.M.: Grundschulverband, 165-176.

ENNEMOSER, M., KUHL, J., \& PEPOUNA, S. (2013). Evaluation des Dialogischen Lesens zur Sprachförderung bei Kindern mit Migrationshintergrund. Zeitschrift für Pädagogische Psychologie 27 (4), 229-239.

FEILKE, H. (2013). Bildungssprache und Schulsprache. In M. Becker-Mrotzek, K. Schramm, E. Thürmann \& H.J. Vollmer (Eds.), Sprache im Fach. Sprachlichkeit und fachliches Lernen. Münster: Waxmann, 113-130.

GHOLAMHOSSEIN, S., \& SIAMAK, S. (2010). The development of L2 speaking skills and the related components: Insight from philosophical questions. Procedia - Social and Behavioral Science, 5, 716-721.

HAYNES, J., \& MURRIS, K. (2012). Picturebooks, Pedagogoy and Philosophy. London: Routledge. 
HELLER, V., \& MOREK, M. (2015). Unterrichtsgespräche als Erwerbskontext: Kommunikative Gelegenheiten für bildungssprachliche Praktiken erkennen und nutzen. Retrieved from http://www.leseforum.ch/myUploadData/files/2015_3_Heller_Morek.pdf

HERING, J. (2010). Leerstellen und das Denken in Möglichkeiten. Bilderbücher und Philosophieren mit Kindern. Grundschulunterricht Sachunterricht 1, 11-15.

HÖVELBRINKS, B. (2014). Bildungssprachliche Kompetenz von einsprachig und mehrsprachig aufwachsenden Kindern. Eine vergleichende Studie in naturwissenschaftlichen Lernumgebungen des ersten Schuljahres. Weinheim/Basel: Beltz Juventa.

KÖNIG, A. (2006). Dialogisch-entwickelnde Interaktionsprozesse zwischen ErzieherIn und Kind(ern). Eine Videostudie aus dem Alltag des Kindergartens. Universität Dortmund: Dissertation.

KÖNIG, A. (2012). Interaktion als didaktisches Prinzip. Bildungsprozesse bewusst begleiten und gestalten. Schaffhausen: Schubi Lernmedien AG.

MARTENS, E. (1999). Philosophieren mit Kindern. Eine Einführung in die Philosophie. Stuttgart: Reclam Verlag.

MARTENS, E. (2002). Philosophieren als elementare Kulturtechnik. In I. Schneider-Wöfinger, \& M. Viertel (Eds.), Philosophieren mit Kindern als vierte Kulturtechnik. Hofgeismar: Evangelische Akademie, 9-22.

MICHALIK, K. (2006). Zur Methodik von Nachdenkgesprächen. Grundschule Sachunterricht, 31, 7-11.

MICHALIK, K. (2010). Methoden des Philosophierens mit Kindern. Grundschulunterricht Sachunterricht, 1, 39-44.

MOL, S. E., BUS, A. G., JONG, M. T. de, \& SMEETS, D. J.H. (2008). Added Value of Dialogic Parent-Child Book Readings: A Meta-Analysis. Early Education \& Development, 19, 7 - 26. Doi: 10.1080/10409280701838603

Morek, M. (2011). Explanative Diskurspraktiken in schulischen und außerschulischen Interaktionen: Ein Kontextvergleich. Schweizerische Zeitschrift für Bildungswissenschaften, 33 (2), 211-230.

NIKLASSON, J., OHLSSON, R., \& RINGBORG, M. (1996). Evaluating Philosophy for Children. Thinking: The Journal of Philosophy for Children, 12 (4), 17-21.

REICH, H. H., \& ROTH, H.-J. (2004): HAVAS 5. Hamburger Verfahren zur Analyse des Sprachstandes Fünfjähriger. Hamburg: Landesinstitut für Lehrerbildung und Schulentwicklung.

RÖHNER, C., KÖNIG, K., HÖVELBRINKS, B., \& ARCHIE, C. (2015). Aufgaben kognitiv anregender Sprachbildung im Elementar und Primarbereich: Empirische Erforschung pädagogisch-didaktischer Ansätze und Möglichkeiten der Professionalisierung. In K. Liebers, B. Landwehr, A. Marquardt, \& K. Schlotter (Eds.), Lernprozessbegleitung und adaptives Lernen in der Grundschule. Jahrbuch Grundschulforschung 19. Wiesbaden: Springer Fachmedien, 79-94. Doi: 10.1007/978-3-658-11346-97

SCHLEIFER, M., \& COURTEMANCHE, L. (1996). The Effect of Philosophy for Children on Language Ability. Thinking: The Journal of Philosophy for Children, 12 (4), 30-31.

SIRAJ-BLATCHFORD, I. (2009). Conceptualising progression in the pedagogy of play and sustained shared thinking in early childhood education: a Vygotskian perspective. Education and Child Psychology, 26 (2), 77-89.

SPINNER, K.H. (2006). Literarisches Lernen. Praxis Deutsch 200, 6-16.

THOMPSON, A. G., \& DUPUIS, A. (1979). Bilingual Philosophy in Milwaukee. Thinking: The Journal of Philosophy for children, 1 (1), 35-39.

TIETZE, S., RANK, A., \& WILDEMANN, A. (2016). Erfassung bildungssprachlicher Kompetenzen von Kindern im Vorschulalter. Grundlagen und Entwicklung einer Ratingskala (RaBi). Retrieved from https://core.ac.uk/download/pdf/44744748.pdf 
philosophising with young children as a language-promoting principle

TRICKEY, S. (2007). Promoting Social and Cognitive Development in Schools: An Evaluation of "Thinking Through Philosophy". The 13th International Conference on Thinking, 187-191. Retrieved from http://www.ep.liu.se/ecp/021/vol1/ecp07021.pdf

WHITEHURST, G. J., FALCO, F. L., LONIGAN, C. J., FISCHEL, J. E., DEBARYSHE, B. D., VALDEZ-MENCHACA, M. C., \& CAULFIELD, M. (1988). Accelerating Language Development Through Picture Book Reading. Developmental Psychology, 24 (4), 552559.

WORLEY, P. (2015). Open thinking, closed questioning: Two kinds of open and closed question. Journal of Philosophy in Schools 2(2), 17-29.

ZEVENBERGEN, A. A., \& WHITEHURST, G. J. (2003). Dialogic reading: A Shared Picture Book Reading Intervention for Preschoolers. In A. van Kleeck, S. A. Stahl, \& E. B. Bauer (Eds.), On reading books to children. Parents and teachers. Mahwah, N.J.: L. Erlbaum Associates, 177-200.

received in: 07.05.2019

accepted in: 10.06.2019 